\begin{tabular}{l|c|c}
\hline ISSN: 0001-5113 & ACTA ADRIAT., & ORIGINAL SCIENTIFIC PAPER \\
AADRAY & $61(2): 145-162,2020$ & \\
\hline
\end{tabular}

\title{
The influence of depth on the Mediterranean reef fish assemblage revealed by the new video on underwater scooter method
}

\author{
Igor GLAVIČIĆ ${ }^{1}$, Marcelo KOVAČIĆ ${ }^{2 *}$, Dejan PALISKA ${ }^{3}$ and Dani LASLO ${ }^{4}$
}

'Department of Marine Studies, University of Split, Livanjska 5, 21000 Split, Croatia

${ }^{2}$ Natural History Museum Rijeka, Lorenzov prolaz 1 HR-51000 Rijeka, Croatia

${ }^{3}$ Faculty for Tourism Studies - Turistica, University of Primorska, Obala 11a, 6320 Portorož, ${ }^{4}$ Ld photography, Pfaffenwiese 135, 65931 Frankfurt am Main, Germany

*Corresponding author:marcelo@prirodoslovni.com

The new video on underwater scooter method in combination with rebreather diving techniques was introduced and applied for visual census of fish assemblages. The presently applied method facilitates deeper visual census studies below $40 \mathrm{~m}$, where they have rarely been done before due to the increasing research challenges with depth. The video on underwater scooter method is also expected to be less disturbing and faster compared to swimming divers. The method was applied in visual census study of fish assemblages from 8 to $50 \mathrm{~m}$ depth conducted at two locations in the east Adriatic using 102 video transects. The environmental variables contributing to the variation of the reef fish community in the depth range of the infralittoral and upper circalittoral bottoms were also recorded. Thirty-one fish species were recorded on transects and $10.3 \%$ of all individuals were not identified to the species level. The average density on transects was 0.8 individuals/ $\mathrm{m}^{2}$, with C. chromis, C. julis and G. auratus being both the most abundant and the most frequent species. Three environmental variables, depth, bottom with zoocover and eastern orientation of the coast, were identified as highly significant for species occurrence. Abundance and species richness of fish assemblages showed no significant variation with depths, inclinations, orientations and sites. A significant difference in the fish assemblage structure was found among orientations, depths and inclinations with the gradient change of species composition with increasing depth and with increasing inclination.

Key words: Underwater visual census, fish community, video transect, depth, Adriatic Sea, closed circuit rebreather 


\section{INTRODUCTION}

The most common observation technique used to study reef fish assemblages is underwater visual census (UVC) with observing and recording the data in situ by SCUBA divers (WATSON et al., 2005). The UVC method was developed in 1950 ' but was not applied in the Mediterranean until two decades later (BROCK, 1954; HARMELINVIVIEN \& HARMELIN, 1975; HARMELIN-VIVIEN et al., 1985). Today, UVC recorded by SCUBA divers is a standard technique used to estimate fish abundance in the field (WARD-PAIGE et al., 2010). The alternative method of UVC, diveroperated video (DOV), has been increasingly used and tested in recent years for observation of infralittoral fish assemblage thanks to improvements and increased quality of video techniques (WATSON et al., 2005; TESSIER et al., 2005; 2013; LAM et al. 2006; PELLETIER et al., 2011; JIND, 2012; ASSIS et al., 2013; HOLMES et al., 2013; WARTENBERG \& BOOTH, 2015; ANDRADI-BROWN et al., 2016a). The DOV is supposed to be able to reach deeper depths, removes diver effects, be cost effective and provide permanent records (CALDWELL et al., 2016).

Underwater visual census methods, in general and in the Mediterranean Sea in particular, have been limited and mostly performed at shallow depth $(<20 \mathrm{~m})$, with the published UVC results on fish assemblages down to 30 $\mathrm{m}$ depth in Mediterranean not common (COLL et al., 1998; GUIDETTI et al., 1998; GUIDETTI et al., 2002; LETOURNEUR et al., 2003; PAIS et al., 2004) and down to $40 \mathrm{~m}-50 \mathrm{~m}$ depth even more rare (FASOLA et al., 1997; RENONES et al., 1997; KOVAČIĆ, 2002; SOLDO \& GLAVIČIĆ, 2013). The long time spent underwater to collect sufficient amount of data and need for qualified and experienced divers who are also skilled enough for identification of fish species, prevent the broad use of UVC at greater depths. In studies, using UVC on the fish assemblage composition in the Mediterranean the depth as variable was rarely assessed. A few published works assessing particularly the influence of depth were limited to $30 \mathrm{~m}$ depth (LETOURNEUR et al., 2003; PAIS et al., 2004), except RENONES et al. (1997) where the deepest transect reached $41 \mathrm{~m}$ depth.
Video-CountN transection was recommended by WARTENBERG \& BOOTH (2015) as the most appropriate method for conducting DOV research and was therefore presently applied. The aims of the paper are:

1) to apply a new video on the underwater scooter method in combination with the rebreather diving techniques for visual census of fishes which is expected to be less disturbing and faster compared to swimming divers, and also facilitate visual census studies of deeper reef fish communities,

2) to identify environmental variables significantly contributing to the variation of the reef fish community at the depth range of the infralittoral and upper circalittoral bottoms by ordination statistics methods, and

3 ) to particularly statistically test the effects of physical and geographical factors (depth, bottom inclination, coastline orientation, locations) on the total fish abundance, species richness, and structure of the reef fish assemblage.

\section{MATERIAL AND METHODS}

\section{Study area and sampling design}

The study was carried out at two locations in the eastern Adriatic Sea on the islands of Hvar: Cape Smočiguzica and Cape Glavna (Fig. 1). Both sites are reefs with a limited width of about 200-300 $\mathrm{m}$ and with steep to vertical limestone bottom at depths ranging between 8 and 55 $\mathrm{m}$. Both locations are similarly exposed to the prevailing weather with waves coming from the NNE, SE and SW.

The visual census was performed on 102 video transects in total from both localities at depth from 8 to $50 \mathrm{~m}$ depth (Table 1). The visual census was carried out by two divers, the main observer (DL) and the supporting diver (IG), using video on underwater scooter (Fig. 2A). The divers used the rebreather equipment JJ- CCR (Closed circuit rebreather) and the scooter Suex Model: XJOY7. Camera was Canon EOS 5D MK II with lens Canon EF $17-40 / 4 \mathrm{~L}$ USM, $17 \mathrm{~mm}$ with a diagonal angle 


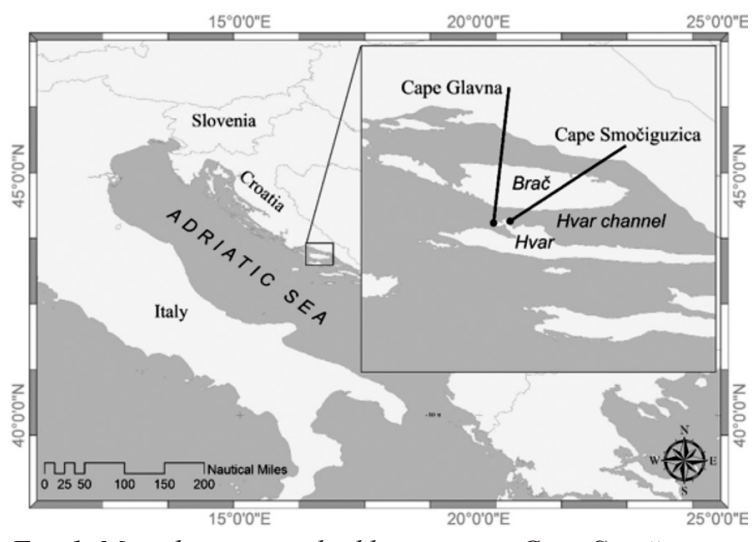

Fig. 1. Map showing studied locations at Cape Smočiguzica and Cape Glavna

of view 104 degrees. The pretesting for finding the optimal equipment and the optimal values and conditions of shooting, and the training of the divers for the procedure took two weeks in September 2015. To avoid seasonal variability the data sampling was carried out in about one week, 2-9 June 2016. All video recordings were taken at approximately the same part of day i.e. between 11 and 16 hours. The visual census belt transect size was $25 \times 2 \mathrm{~m}$. The Video-CountN transect method was adapted from WARTENBERG \& BOOTH (2015).

In the pretesting process the optimal equipment, values and recording condition were investigated, including the choice of camera model, camera lenses, lighting, the best camera angle to record both epibenthic and hyperbenthic fishes, the maximum speed of the underwater scooter at which the fish are still identifiable and countable, and the distance of camera from the ground needed to adjust $2 \mathrm{~m}$ transect width. During the two-week pre-test phase, in addition to the finding of the optimal equipment and values and condition of shooting, the divers were trained for procedure and to maintain the distance to the bottom, to keep the correct camera angle, and to follow isobaths of the appropriate depths.

The width of the present digital transects was determined by the field of view of the camera lens (WARTENBERG \& BOOTH, 2015). The conclusion from the pretesting was that the cameraman should drive an underwater scooter $1.5 \mathrm{~m}$ above the bottom and hold the video camera steady in front of him at an angle of 45 degrees to the
Table 1. Number of transects

\begin{tabular}{ll}
\hline Depth $(\mathrm{m})$ & Number of transects \\
\hline 8 to 10 & 29 \\
15 to 20 & 27 \\
30 to 35 & 23 \\
45 to 50 & 23 \\
\hline Total & 102 \\
\hline
\end{tabular}

bottom to ensure width of the transects of $2 \mathrm{~m}$ (Fig. 2B and 2C). However, due to the steep to vertical bottom, camera had to be angled 45 degrees to left-right and not up-down direction (Fig. 2A and 2B).

In order to avoid deploying of the transect line needed to define the transect length, thereby to reduce the diver disturbance of the bottom and to optimize the dive time (WARTENBERG \& ВООТН, 2015), the transects were terminated after a fixed time, based on relationship of distance and time from the constant speed of the underwater scooter. Regarding the speed of the underwater scooter at which fishes are still identifiable, the pretesting showed that the slowest among tested underwater speeds was the best for the recognizing of fishes. The speed of a scooter with an equipment configuration (Fig. 2A) was $0.7 \mathrm{~m} / \mathrm{s}$, resulting in 36 seconds of time needed to pass $25 \mathrm{~m}$ transect. The visual census was performed in the conditions of absent sea current so the length of transects could be determined on the time passed. The continuing recording of transects along the same depth should be separated by intervals (ANDRADI-BROWN et al., 2016a; 2016b). Therefore, the divers conducted continuous filming of several transects and the intervals between them at once in a line approximately following isobaths.

Sampling was conducted by divers in buddy team. During transecting, the primary observer (DL) in a buddy pair set the speed of underwater scooter and drove it, recording digital footage and control time for the termination of transect series. The role of supporting diver (IG) at the beginning of each transect series was to check if the horizontal visibility is good enough and if the sea current is absent not to influence the visual census and distance estimation; to establish the 

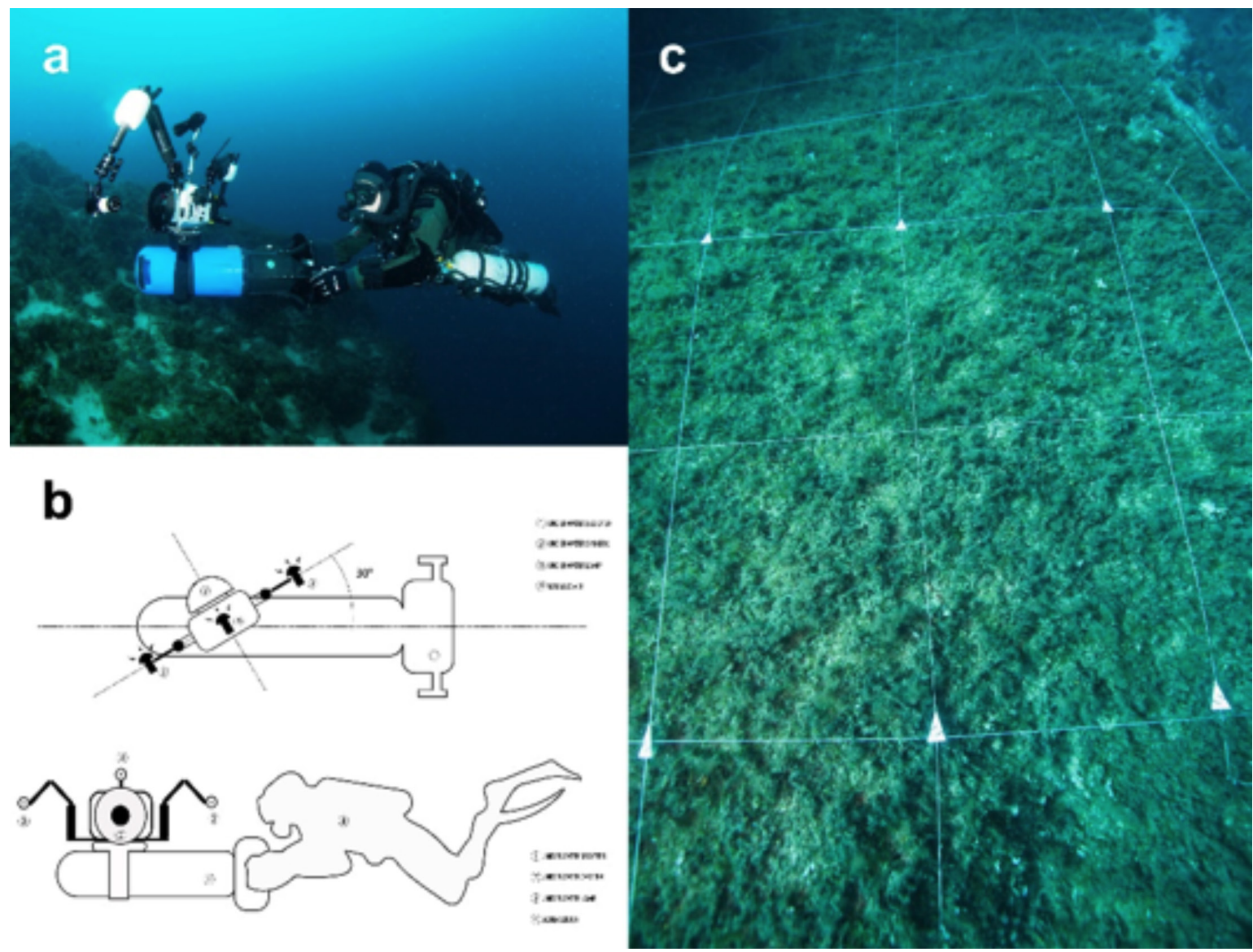

Fig. 2. a) The primary observer with full equipment, b) sketch of the mounted equipment and camera angle, c) camera view when positioned $1.5 \mathrm{~m}$ from the bottom and with an angle of 45 degree, grid 1 by $1 \mathrm{~m}$, the view width at the closest point $2 \mathrm{~m}$, widening forward out of $2 \mathrm{~m}$ wide marks, the view length about $5 \mathrm{~m}$, visible from grid. The photos and drawing by Dani Laslo

starting point of transect series and to check at shooting beginning the distance of camera from the bottom by calibrated stick. The occurrence of a sea current was tested with a very fine bottom sediment, fine sand was dropped by second diver about $50 \mathrm{~cm}$ above the bottom before each survey depth, in case the sediment descends vertically to the bottom, no current is present and sampling can start. The supporting diver also recorded in situ water temperature, depth, date, time and orientation of each transect. The role of supporting diver who followed the first one during transects on the second underwater scooter was to control the procedure i.e. to control if the camera distance from the bottom and the depth i.e. following of isobaths were kept.

\section{Media techniques and analysis}

The video clips of 36 seconds from each continuous filming, which is equal to $25 \mathrm{~m}$ long transects (see in Study area and sampling design above), were extracted from original shooting, each with additional 14 seconds excluded as interval between transects. The initial part of video with preparation and calibration on the beginning of each shooting was also excluded. Each transect images were analyzed on a 27' screen by the fish expert (MK), using standard viewing software that enables slow view and zooming (MPC-HC 1.7.10), HPC-HC team, http://hpc-hc.org). Video clips were analysed on the half of the normal speed, but also using multiple pauses, additional slowing down, rewinds 
and repeated playbacks whenever necessary (WARTENBERG \& BOOTH, 2015). Video-CountN transecting is recommended as the most appropriate method for conducting DOVs providing highest estimates of richness and abundance, the lowest variability, the most representative diversity being also the most efficient considering time consuming (WARTENBERG \& BOOTH, 2015). The CountN analysis simply identifies and enumerates all individuals observed in digital transects, effectively imitating in situ slatetransect enumeration. Individuals that could not be accurately identified to the species level because they were too far away, moved through the census area too rapidly, or were obscured due to poor lighting, camera angle, individual orientation or other factors, were categorized as unidentifiable, even if it was possible to identify them to higher taxon (WARTENBERG \& BOOTH, 2015). In digital CountN analyses of all transects, first check of video clip was performed to record all present species; the second check focused on search for possible presence of fish at bottom, staying still; on the third check number of individuals of species occurring at lower densities, i.e. $<10$ individuals per transect, were counted simultaneously. The species that occurred at higher abundances, i.e. $>10$ individuals per transect were counted in separate checks/counts for each species. Counts from digital transects were corroborated by reanalyzing the media. It was assumed that if two counts for a particular transect were sufficiently similar, then those counts would have been acceptably close to the true count generated by the technique. Re-analysis was conducted 2 weeks after the original counts were completed (WARTENBERG \& BOOTH, 2015). Percentage agreement was applied to the species observed (presence/absence) and to speciesspecific abundance for each digital transect-type analysis technique combination (WARTENBERG \& BOOTH, 2015). Minimum agreement in species presence/absence was set to $100 \%$ because if a species is observed during initial analysis it should be observed in all subsequent reviews. Minimum species-specific abundance agreement was set to $100 \%$ for species observed with $<10$ individuals per transect, and to $90 \%$ for species observed with $>10$ individuals per transect. A 10\% difference in counts was considered acceptable due to the challenges of counting abundant or shoaling species in motion. When single species abundances were between $90 \%$ and $100 \%$ agreement, the mean of the two abundance estimates from the two stages of analysis was accepted as the final value. When more than one reanalysis was necessary, the percentage agreement rule was applied to the two last rounds of analysis where the minimum $90 \%$ agreement was reached. The same percentage rules were also applied to fishes categorized as unidentifiable thereby corroborating counts of all observed individuals. In addition to abundance of each recorded fish species on each transects, the supplementary habitat variables were also estimated from each digital transects in the separate check of video for each habitat variable after the fish counts: bottom inclination, bottom substrate and biocover. The variable categories were modified from KOVAČIĆ et al. (2012). The samples were taken at four distinct, non-contacted depth ranges and "Depth" variable was accordingly divided: $8-10 \mathrm{~m}, 15-20 \mathrm{~m}$, 30-35 $\mathrm{m}$ and 45-50 $\mathrm{m}$ depth. "Inclination" as three estimated classes: gentle to moderate $\left(<30^{\circ}\right)$, steep $\left(30^{\circ}-60^{\circ}\right)$ and very steep to vertical $\left(>60^{\circ}\right)$. "Bottom substrate" as four types of different estimated particle size and three kinds of bedrock surfaces (sand, gravel $<60 \mathrm{~mm}$, cobbles $<200 \mathrm{~mm}$, boulders $>200 \mathrm{~mm}$, bedrock with more or less smooth surface, bedrock with crevices and cavities, high relief bedrock composed of ridges and trenches). "Biocover" as six types (no biocover, phanerogams, long thallus algae, short thallus algae, calcaerous algae, zoocover). Each of the categories of "Bottom substrate" and "Biocover" present in particular sample was expressed as estimated percentage $(10 \%, 20 \%$ $\ldots 100 \%)$ of the total surface in that sample. "Orientation" of transect was general orientation parallel to the coast as North, East and West, missing South orientation due to the coast orientation at localities. "Depth", "Inclination", "Orientation" therefore can be used as factors with levels, contrary to the recorded estimated percentages of bottom substrate and of the percentages of biocover types. 
Table 2. The total number of recorded individuals for species and the frequency of species occurrence at the transects (n =102). The number of fish is a sum on all transects. Some transects values were with decimal fractions, being the average of two counts (see Media techniques and analysis in Material and methods), with the rounding done only on the final numbers presented here

\begin{tabular}{|c|c|c|c|}
\hline Species & Abbreviation & $\begin{array}{l}\text { Total } \\
\text { number of } \\
\text { recorded } \\
\text { individuals }\end{array}$ & $\begin{array}{l}\text { Species } \\
\text { frequency of } \\
\text { occurrence }\end{array}$ \\
\hline Boops boops (Linnaeus, 1758) & Bo bo & 2 & $2.0 \%$ \\
\hline Chromis chromis (Linnaeus, 1758) & Ch ch & 2667 & $85.3 \%$ \\
\hline Coris julis (Linnaeus, 1758) & Co ju & 318 & $72.5 \%$ \\
\hline Diplodus annularis (Linnaeus, 1758) & Di an & 17 & $9.8 \%$ \\
\hline Diplodus puntazzo (Cetti, 1777) & Di pu & 1 & $1.0 \%$ \\
\hline Diplodus sargus (Linnaeus, 1758) & Di sa & 6 & $2.0 \%$ \\
\hline Diplodus vulgaris (Geoffroy St. Hilaire, 1817) & Di vu & 113 & $35.3 \%$ \\
\hline Gobius auratus (Risso, 1810) & Go au & 321 & $55.9 \%$ \\
\hline Gobius geniporus (Valenciennes, 1837) & Go ge & 1 & $1.0 \%$ \\
\hline Gobius vittatus (Vinciguerra, 1883) & Go vi & 9 & $2.9 \%$ \\
\hline Labrus mixtus (Linnaeus, 1758) & La mi & 2 & $2.0 \%$ \\
\hline Mullus surmuletus (Linnaeus, 1758) & $\mathrm{Mu} \mathrm{su}$ & 2 & $1.0 \%$ \\
\hline Oblada melanura (Linnaeus, 1758) & $\mathrm{Ob}$ me & 2 & $1.0 \%$ \\
\hline Parablennius rouxi (Cocco, 1833$)$ & Pa ro & 13 & $9.8 \%$ \\
\hline Phycis phycis (Linnaeus, 1766) & $\mathrm{Ph} \mathrm{ph}$ & 4 & $2.0 \%$ \\
\hline Sarpa salpa (Linnaeus, 1758) & Sa sa & 1 & $1.0 \%$ \\
\hline Scorpaena porcus Linnaeus, 1758 & Sc po & 3 & $2.9 \%$ \\
\hline Serranus hepatus (Linnaeus, 1758) & Se he & 1 & $1.0 \%$ \\
\hline Serranus scriba (Linnaeus, 1758) & Se sc & 43 & $23.5 \%$ \\
\hline Serranus cabrilla (Linnaeus, 1758) & Se ca & 13 & $12.7 \%$ \\
\hline Spicara smaris (Linnaeus, 1758) & Sp sm & 74 & $4.9 \%$ \\
\hline Spicara flexuosa Rafinesque, 1810 & Sp fl & 3 & $2.0 \%$ \\
\hline Spondyliosoma cantharus (Linnaeus, 1758) & Sp ca & 5 & $3.9 \%$ \\
\hline Symphodus doderleini (Jordan, 1890) & Sy do & 2 & $2.0 \%$ \\
\hline Symphodus mediterraneus (Linnaeus, 1758) & Sy med & 13 & $9.9 \%$ \\
\hline Symphodus melanocercus (Risso, 1810) & Sy mel & 3 & $2.9 \%$ \\
\hline Symphodus ocellatus (Linnaeus, 1758) & Sy oc & 3 & $2.0 \%$ \\
\hline Symphodus tinca (Linnaeus, 1758) & Sy ti & 26 & $16.7 \%$ \\
\hline Thorogobius ephippiatus (Lowe, 1839) & Th ep & 5 & $3.9 \%$ \\
\hline Tripterygion delaisi Cadenat \& Blanche, 1971 & $\operatorname{Tr}$ de & 3 & $2.9 \%$ \\
\hline Tripterygion tripteronotum (Risso, 1810) & $\operatorname{Tr} \operatorname{tr}$ & 2 & $2.0 \%$ \\
\hline
\end{tabular}




\section{Data analysis}

In order to determine the relationship between environmental variables and the fish assemblage Canonical correspondence analysis (CCA) (TER BRAAK, 1986; 1994) was carried out using CANOCO software (TER BRAAK, 1992). All fish species recorded on the transects were used for analysis (Table 2). The species abundance were $\log (\mathrm{x}+1)$ transformed to normalize the distribution. To reveal patterns of species response curves in relation to environmental gradients, data sets were first analyzed with Detrended Correspondence Analysis (DCA). The first axis gradient length measured in turnover (or SD units) indicated nonlinear or unimodal responses, therefore a Canonical Correspondence Analysis (CCA) was chosen as a constrained ordination method.
Among the 19 possible environmental variables included in the field recording sheet (in CCA factors with levels being just qualitative categories were decomposed and each level treated as separate environmental variables), 14 variables were actually recorded during fieldwork (Table $3)$.

Locality was introduced into the model as co-variable to partial out possible confounding effects varying between locations using partial constrained analysis. The first CCA was performed with all actually recorded environmental variables and the forward selection procedure was then used to extract the variables incorporated in the final model. In order to avoid inflated significance values, redundant predictor variables, i.e. environmental variables showing high multicolinearity $(\mathrm{VIF}>10)$, were removed

Table 3. Variation explained by 14 and by 11 environmental variables. Marginal effect ( $\lambda 1)$ of environmental variable refers to eigenvalues fit if the corresponding variable was the only environmental variable in the model. The conditional effect ( $\lambda$ A) refers to the additional amount of explained variance in species distribution by the correspondent variable when selected by automatic forward selection. The obtained statistics of the Monte Carlo permutation test under the full model with 999 random permutations ( $P$-value and F) are reported for each variable. Significant conditional effect in models with 14 and with 11 environmental variables $(P \leq 0.05)$ in bold

\begin{tabular}{|c|c|c|c|c|c|c|c|}
\hline \multirow[b]{3}{*}{ Variable } & \multirow{3}{*}{$\begin{array}{l}\text { Marginal } \\
\text { Effects } \\
\lambda 1\end{array}$} & \multicolumn{6}{|c|}{ Conditional Effects after forward selection } \\
\hline & & \multicolumn{3}{|c|}{14 Environmental variables } & \multicolumn{3}{|c|}{11 Environmental variables } \\
\hline & & $\lambda \mathrm{A}$ & $\mathrm{P}$ & $\mathrm{F}$ & $\lambda \mathrm{A}$ & $\mathrm{P}$ & $\mathrm{F}$ \\
\hline Depth & 0.15 & 0.15 & 0.002 & 4.21 & 0.15 & 0.002 & 4.21 \\
\hline Zoocover & 0.13 & 0.1 & 0.002 & 2.91 & 0.11 & 0.002 & 2.86 \\
\hline Calcareous algae & 0.12 & 0.07 & 0.016 & 1.96 & 0.07 & 0.016 & 1.93 \\
\hline $\begin{array}{l}\text { High relief bedrock } \\
\text { composed of ridges and } \\
\text { trenches }\end{array}$ & 0.1 & 0.11 & 0.014 & 2.95 & $\mathrm{n} / \mathrm{a}$ & $\mathrm{n} / \mathrm{a}$ & $\mathrm{n} / \mathrm{a}$ \\
\hline Short thallus algae & 0.1 & 0.03 & 0.554 & 0.77 & 0.02 & 0.598 & 0.69 \\
\hline Inclination & 0.1 & 0.06 & 0.008 & 1.82 & 0.05 & 0.046 & 1.59 \\
\hline East & 0.09 & 0.09 & 0.002 & 2.56 & 0.09 & 0.002 & 2.5 \\
\hline Sand & 0.08 & 0.05 & 0.224 & 1.31 & 0.06 & 0.07 & 1.69 \\
\hline Long thallus algae & 0.08 & 0.07 & 0.018 & 2.08 & 0.07 & 0.022 & 2.08 \\
\hline West & 0.07 & $\mathrm{n} / \mathrm{a}$ & $\mathrm{n} / \mathrm{a}$ & $\mathrm{n} / \mathrm{a}$ & $\mathrm{n} / \mathrm{a}$ & $\mathrm{n} / \mathrm{a}$ & \\
\hline No biocover & 0.07 & 0.02 & 0.9 & 0.62 & 0.02 & 0.94 & 0.57 \\
\hline $\begin{array}{l}\text { Bedrock with crevices } \\
\text { and cavities }\end{array}$ & 0.05 & 0.03 & 0.392 & 0.9 & 0.07 & 0.012 & 2.06 \\
\hline $\begin{array}{l}\text { Bedrock with more or } \\
\text { less smooth surface }\end{array}$ & 0.05 & 0.02 & 0.844 & 0.69 & 0.05 & 0.046 & 1.52 \\
\hline North & 0.03 & 0.04 & 0.22 & 1.18 & $\mathrm{n} / \mathrm{a}$ & $\mathrm{n} / \mathrm{a}$ & $\mathrm{n} / \mathrm{a}$ \\
\hline
\end{tabular}


from the model resulting in the final model with 11 environmental variables. The significance of the canonical axes and of the environmental variables was determined using Monte Carlo permutation tests (with 999 random permutations). The CCA was run with a focus on interspecies distances and the biplot scaling option.

The ANOVA assumptions were not met in the data for the comparisons of abundance (the total number of all individuals) and species richness (total number of recorded species) at different depths, inclinations, orientations and sites. Therefore the changes in abundance and richness among depths (8-10 m, 15-20 m, 30-35 m, 45-50 $\mathrm{m})$, inclinations $\left(<30^{\circ}, 30^{\circ}-60^{\circ},>60^{\circ}\right)$, orientations $(\mathrm{N}, \mathrm{E}, \mathrm{W})$ and between two sampling sites (Cape Glavna, Cape Smočiguzica) were each examined with one-way Permutational multivariate Analysis of variance (PERMANOVA) (ANDERSON, 2001) with 999 permutation on untransformed data using Euclidian distances.

To address the possible differences in fish assemblage structures among depths, inclinations, orientations and between sampling sites we used one-way PERMANOVA, for each factor separately, with 999 permutation on $\log (\mathrm{x}+1)$ transformed data using Bray-Curtis similarity matrix. Relevant factors were additionally tested for interaction effect with two-way PERMANOVA. All factors were treated as fixed. To graphically visualize the difference in fish assemblage structures, nonparametric multidimensional scaling (nMDS) plots (FIELD et al., 1982) were performed. In cases when one-way PERMANOVA was significant $(\mathrm{P}<0.05)$, pairwise comparison was conducted using pairwiseAdonis (ARBIZU, 2019) in R. The nMDS ordination plots were run using Bray-Curtis similarity matrix. We used $R$ statistical package and vegan library to run all analyses.

\section{RESULTS}

\section{Diversity, abundance and frequency of fishes}

Thirty-one fish species were recorded on the 102 transects with the total number of 3677 identified individuals (Table 2) and with additional 396 individuals (10.3\% of all individuals) unidentified to the species level for the reasons listed in Material and methods. The present method was able to detect and identify benthic fish down to the size of about 8-10 cm (Gobius geniporus (Valenciennes, 1837), Thorogobius ephippiatus (Lowe, 1839)). Below that size only strikingly colored benthic species were noticed and identified due to the limits of resolution and illumination (Gobius auratus Risso, Gobius vittatus (Vinciguerra, 1883), males of Tripterygion delaisi Cadenat \& Blanche, 1971 and Tripterygion tripteronotum (Risso, 1810)). The average number of all individuals per transect was 39.9, resulting in average density of 0.8 individuals/ $\mathrm{m}^{2}$. Chromis chromis (Linnaeus, 1758) was the most abundant species, with $72.5 \%$ of all identified individuals belonging to this species, followed by Gobius auratus Risso, 1810 (8.7\%), Coris julis (Linnaeus, 1758) (8.6\%) and Diplodus vulgaris (Geoffroy St. Hilaire, 1817) (3.1\%). None of the other species was recorded with more than hundred recorded individuals, and 20 species were recorded with less than ten individuals, which all together represented just $1.6 \%$ of all identified individuals (Table 2). The most frequent species were again the same three most abundant species: C. chromis (frequency of occurrence on transects $85.3 \%)$, C. julis (72.5\%) and G. auratus $(55.9 \%)$, four more species were more frequent than $10 \%$, but 8 species were recorded on just two transects and 6 species on only one transect (Table 2). The most diverse family was Sparidae (9 species) followed by Labridae (7 species).

\section{Important habitat variables structuring the fish assemblage at the infralittoral and upper circalittoral rocky and mixed bottoms}

The first partial CCA was performed with 14 environmental variables on all 31 species as response variables (Fig. 3A). The Monte Carlo permutation test was statistically significant on the first axis and also on all canonical axes (Table 3). The cumulative percentage of variance in the response data explained by the first four constrained axes was $14.2 \%$, and the first four axes explained $64.1 \%$ of variation 
in the response data explained by explanatory variables i.e. of the variation of fitted response values (Table 3). The model with 11 environmental variables, after the forward selection procedure excluded redundant variables (North, West, High relief bedrock composed of ridges and trenches), showed slightly lower cumulative explained variation (13.7\%) and slightly higher cumulative fitted explained variation (68.0\%) than the model with 14 environmental variables (Fig. 3B, Tables 4 and 5).

Canonical eigenvalues are also slightly lower in the model with 11 environmental variables (Tables 4 and 5). The forward selection identified three highly significant environmental variables: Depth, Zoocover and East $(\mathrm{P}=0.002 \%)$, and, in the model with 11 environmental variables, the five other significant variables: Inclination, Bedrock with crevices and cavities, Bedrock with more or less smooth surface, Long thallus and Calcareous algae (Table 3). Among highly significant variables the first axis was positively correlated with Depth and Zoocover and negatively correlated with East, while a further positive correlation is detectable also with other three significant variables (Inclination, Bedrock with crevices and cavities, Calcareous algae) (Fig. 3, Table 3). The second axis correlate, among significant environmental variables, with Long thallus algae. The projections of species points of Phycis phycis (Linnaeus, 1766), Boops boops (Linnaeus, 1758), Labrus mixtus Linnaeus, 1758 and T. ephippiatus onto highly significant environmental variables Depth and Zoocover, but also onto significant Inclination, Bedrock with crevices and cavities and Calcareous algae, show optima of these species at high values of these environmental variables i.e. at deep, steep bedrock with crevices and cavities covered with sedentary animals and calcareous algae, contrary to species negatively correlated to these variables: G. geniporus, Mullus surmuletus (Linnaeus, 1758), Serranus scriba (Linnaeus, 1758), T. tripteronotum. The projections of species points of several wrasses (Coris julis (Linnaeus, 1758), Symphodus doderleini Jordan, 1890, S. mediterraneus (Linnaeus, 1758), S. ocellatus (Linnaeus, 1758)), and also of

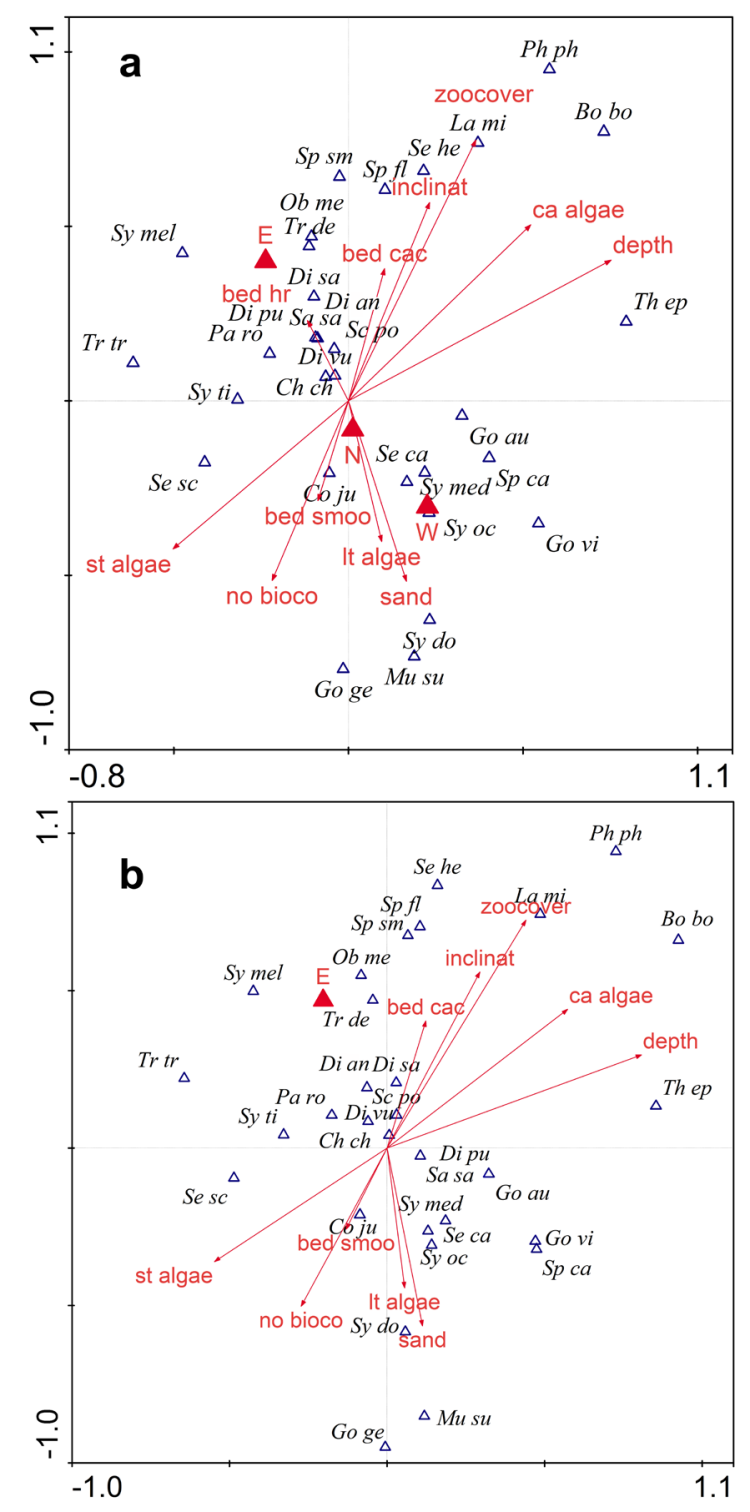

Fig. 3. CCA species-environment biplot for all 14 environmental variables $(A)$ and final model with 11 environmental variables (B) (biplot scaling). Quantitative environmental variables are represented by arrows and nominal variable is indicated by a triangle, both red and with abbreviations in regular font. The abbreviations for explanatory variables: depth - Depth, E-East, $W$ - West, $N$ - North, inclinat - Inclination, sand - Sand, bed smoo - Bedrock with more or less smooth surface, bed cac-Bedrock with crevices and cavities, bed $h r-H i g h$ relief bedrock composed of ridges and trenches, no bioco - No biocover, lt alage - Long thallus algae, st algae - Short thallus algae, ca algae - Calcareous algae, zoocover - Zoocover. Hollow triangles and abbreviations in italics represent fish species. The abbreviations for fish species are explained in Table 2. 
Table 4. Outcome of CCA, using 14 environmental variables. Significance of environmental variables are reported in Table 3

\begin{tabular}{llllll}
\hline Total inertia $=$ & \multicolumn{1}{c}{3.855} & & & & \\
Sum of canonical eigenvalues $=$ & 0.837 & Axis 1 & Axis 2 & Axis 3 & Axis 4 \\
Eigenvalues & & 0.182 & 0.151 & 0.123 & 0.081 \\
Species-environment (S-E) correlations & 0.782 & 0.741 & 0.715 & 0.629 \\
Cumulative \% variance of species data & 4.8 & 8.8 & 12.0 & 14.2 \\
Cumulative \% variance of S-E relation & 21.8 & 39.8 & 54.4 & 64.1 \\
Monte Carlo test (P-value, 999 permutations) & 0.002 & P (All canonical axes) $=0.016$ \\
\hline
\end{tabular}

Table 5. Outcome of CCA, using 11 environmental variables. Significance of environmental variables are reported in Table 3

\begin{tabular}{|c|c|c|c|c|c|}
\hline \multicolumn{6}{|l|}{ Total inertia $=\quad 3.855$} \\
\hline \multicolumn{2}{|l|}{ Sum of canonical eigenvalues $=$} & Axis 1 & Axis 2 & Axis 3 & Axis 4 \\
\hline \multicolumn{2}{|l|}{ Eigenvalues } & 0.177 & 0.146 & 0.118 & 0.078 \\
\hline \multicolumn{2}{|c|}{ Species-environment (S-E) correlations } & 0.779 & 0.740 & 0.700 & 0.600 \\
\hline \multicolumn{2}{|c|}{ Cumulative $\%$ variance of species data } & 4.7 & 8.5 & 11.6 & 13.7 \\
\hline \multicolumn{2}{|c|}{ Cumulative $\%$ variance of S-E relation } & 23.2 & 42.3 & 57.8 & 68.0 \\
\hline \multicolumn{2}{|c|}{ Monte Carlo test (P-value, 999 permutations) } & 0.004 & \multicolumn{3}{|c|}{$\mathrm{P}($ All canonical axes $)=0.014$} \\
\hline
\end{tabular}

Spondyliosoma cantharus (Linnaeus, 1758) and Serranus cabrilla (Linnaeus, 1758) on significant environmental variable Long thallus algae show positive correlation of these species to the habitat with long thallus algae, while the similar biplot positions of G. geniporus, M. surmuletus and also $G$. vittatus is probably more related to another quantitative predictor, Sand, which is highly overlapped with Long thallus algae, and had large but not significant effect. The deep bottom species $P$. phycis and L. mixtus, benthopelagic species Spicara flexuosa Rafinesque, 1810, S. smaris (Linnaeus, 1758) and Oblada melanura (Linnaeus, 1758), and also Serranus hepatus (Linnaeus, 1758) avoided of Long thallus algae habitat.

\section{The variation of the fish abundance, species richness and fish assemblage}

\section{structure with depths, inclinations, orientations and sites}

PERMANOVA for the differences in total fish abundance and the species richness showed no significant differences with depths, inclinations, orientations and sites (Table 6).

However, the PERMANOVA test on the fish assemblage structure indicates the significant difference in fish assemblage structures among different orientations, depths and inclinations, while sites didn't have significant influence on the fish assemblage composition (Table 7). The post hoc test reveals that the fish assemblage at shallow depth, $8-10 \mathrm{~m}$, is different from the fish assemblages at all other depths, but also that the fish assemblage composition at the depth $15-20 \mathrm{~m}$ is again significantly different from the largest depth, 45-50 $\mathrm{m}$ (Table 7). The pairwise PERMANOVA also indicated the significant difference in fish assemblage between extreme inclinations i.e. $<30^{\circ}$ and $>60^{\circ}$ (Table 7). The results of the pairwise comparison for depths 
Table 6. Results of one-way PERMANOVA tests comparing total fish abundance and species richness of fish assemblages according to four factors: Depth $(8-10 \mathrm{~m}, 15-20 \mathrm{~m}, 30-35 \mathrm{~m}, 45-50 \mathrm{~m})$, Inclination $\left(<30^{\circ}, 30^{\circ}-60^{\circ},>60^{\circ}\right)$, Orientation (North, East, West) and Sites (Cape Glavna, Cape Smočigizica). ${ }^{*} P<0.05 ; * * P<0.001 ;$ n.s. $=$ not significant. Analyses were conducted on untransformed data using Euclidian distances

\begin{tabular}{lllllllll}
\hline & \multicolumn{3}{l}{ ABUNDANCE } & \multicolumn{3}{l}{ SPECIES RICHNESS } \\
\hline Source of variation & df & Pseudo F & P $($ perm $)$ & & \multicolumn{2}{c}{ Pseudo F } & P (perm) \\
\hline Site & 1 & 0.014 & 0.923 & n.s. & 0.625 & 0.426 & n.s. \\
Orientation & 2 & 1.425 & 0.259 & n.s. & 0.642 & 0.544 & n.s. \\
Depth & 3 & 0.956 & 0.407 & n.s. & 0.465 & 0.725 & n.s. \\
Inclination & 2 & 1.758 & 0.182 & n.s. & 2.394 & 0.084 & n.s. \\
\hline
\end{tabular}

and for inclinations therefore imply the gradient changes in species composition with the increasing depth and with the increasing inclination. In addition, it looks like the intensity of changes in species composition was larger in shallow water since $8-10 \mathrm{~m}$ and $15-20 \mathrm{~m}$ were the only neigh-

Table 7. Results of PERMANOVA tests comparing fish assemblage structure according to four factors: Depth (8-10 m, 15-20 m, 30-35 m, 45-50 m), Inclination $\left(<30^{\circ}, 30^{\circ}-60^{\circ},>60^{\circ}\right)$, Orientation (North, East, West) and Sites (Cape Glavna, Cape Smočigizica). ${ }^{*} P<0.05$; $* * P<0.001 ;$ n.s. $=$ not significant. Results of pairwise comparison are reported only for factors with more than two levels having significant $(P<0.05)$ difference. All data were $\log (x+1)$ transformed

\begin{tabular}{lllll} 
Source of variation & df & Pseudo F & P (perm) & \\
\hline Site & 1 & 0.812 & 0.537 & n.s. \\
Orientation & 2 & 3.369 & 0.03 & $*$ \\
Depth & 3 & 15.589 & $<0.001$ & $* *$ \\
Inclination & 2 & 9.574 & $<0.001$ & $* *$ \\
\hline Pairwise comparison & & & & \\
\hline Orientation & & & \\
\hline \multicolumn{1}{c}{ E vs N } & & & & \\
\hline \multicolumn{1}{c}{ E vs W } & 4.58 & 0.06 & \\
\hline N vs W & 3.36 & 0.022 & $*$ \\
\hline Depth (m) & & & \\
$8-10$ vs $15-20$ & 12.05 & $<0.001$ & $* *$ \\
$8-10$ vs $30-35$ & 15.952 & $<0.001$ & $* *$ \\
$8-10$ vs $45-50$ & 19.464 & $<0.001$ & $* *$ \\
$15-20$ vs $45-50$ & 3.421 & 0.025 & $*$ \\
Inclination & & & $* 0.001$ \\
$\quad<30^{\circ}$ vs $>60^{\circ}$ & 9.31 & $<*$ \\
\hline
\end{tabular}

boring depth ranges with significantly different fish assemblage composition. The nMDS plots illustrated the differentiation of fish assemblage species composition among depths (Fig. 4A), inclinations (Fig. 4B) and orientations (Fig. 4C) found by the PERMANOVA test, while there was no separation on the nMDS ordination plot between fish assemblage species composition at different sites, matching again the PERMANOVA results (Fig. 4D). Even the significant differences established from the pairwise comparison are visible on the nMDS plots as the larger distances between centroids of those levels on the plots (Table 7, Fig. 4A and 4B). There was also the significant interaction between site and depth, site and orientation and orientation and depth found by the two-way PERMANOVA (Table 8), meaning that the effect of depth varied between sites and among different orientations and the effect of orientation varied between sites.

Table 8. Results of two-way PERMANOVA tests comparing fish assemblage structure. ${ }^{*} P<0.05 ; * * P<0.001$; n.s. =not significant

\begin{tabular}{lllll}
\hline Source of variation & df & Pseudo F & P (perm) & \\
\hline Site x Depth & 3 & 2.376 & 0.01 & $*$ \\
Site x Orientation & 2 & 3.660 & 0.02 & $*$ \\
Site x Inclination & 5 & 0.221 & 0.956 & n.s \\
Depth x Inclination & 5 & 0.925 & 0.522 & n.s \\
Depth x Orientation & 5 & 2.020 & 0.015 & $*$ \\
\hline
\end{tabular}



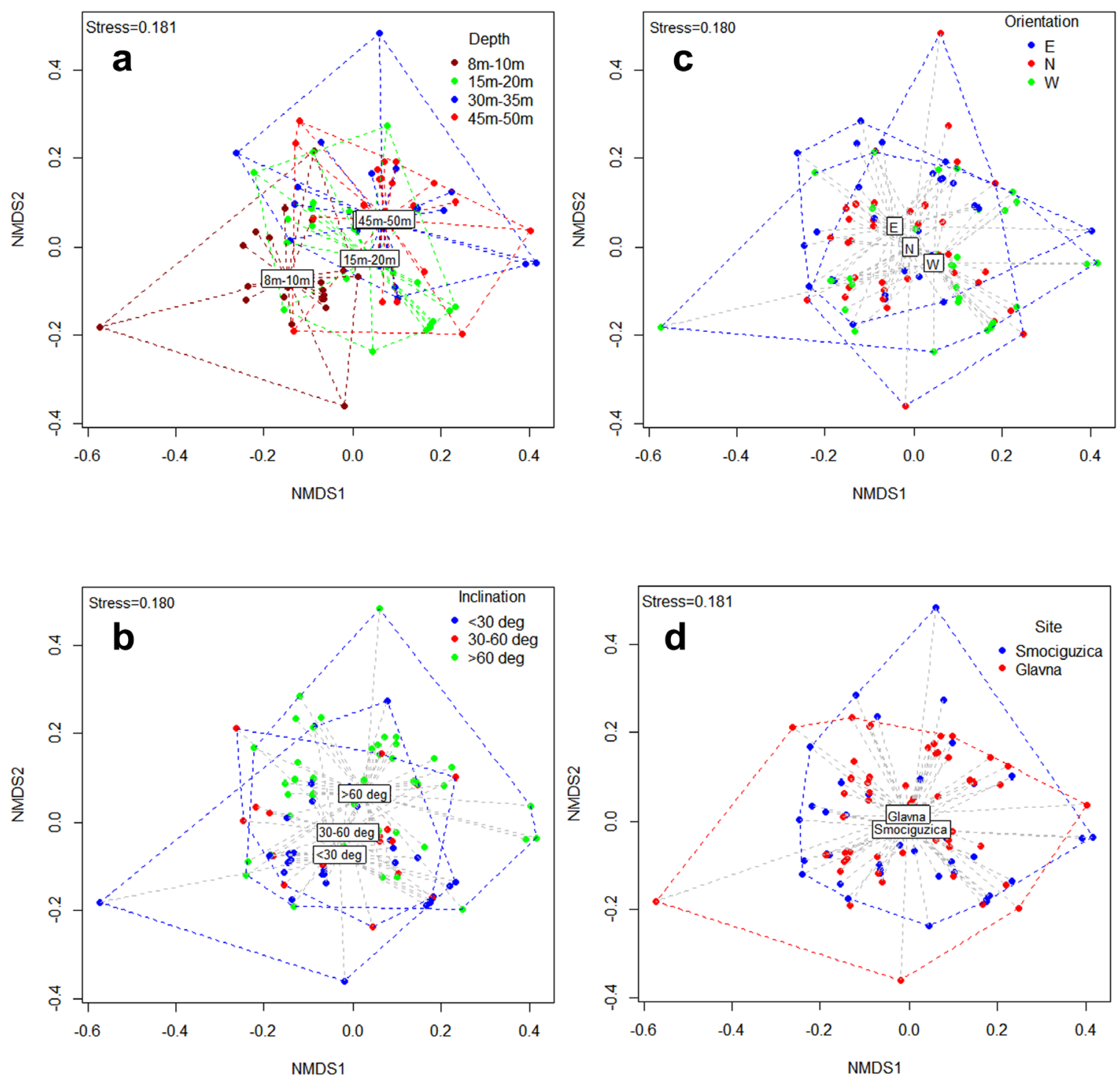

Fig. 4. Non-metric multi-dimensional scaling (nMDS) ordination plot of individual transects comparing (a) depth: $8-10 \mathrm{~m}$ (brown circles), 15-20 m (green circles), 30-35 m (blue circles), 45-50 m (red circles); (b) inclination: $<30^{\circ}$ (blue circles), $30^{\circ}-60^{\circ}$ (red circles), $>60^{\circ}$ (green circles); (c) Orientation: North (blue circles), East (red circles), West (green circles); (d) Site: Smočiguzica (blue circles), Glavna (red circles). Stress values presented on each graph.

\section{DISCUSSION}

The present method showed to be limited to detect and identify benthic fish below a size of about 8-10 cm, except for the conspicuously colored fish, due to the limits of resolution and illumination. Similar to other DOV studies and to UVC methods in general, in the present study we were also not able to detect cryptobenthic fishes (KOVAČIĆ et al., 2012), which are by definition, hidden in bottom space and out of reach by the visual methods. Therefore, the presently described fish assemblages are incomplete lacking these parts of the fish assemblage. This general limitation of visual methods prevents the visual census from being able to describe the entire fish assemblage of the bottom habitats.

In comparison with other visual censuses carried out, which also examined the influence of depth on the fish assemblage composition in the Mediterranean, the present data showed lover total diversity (31 species recorded over 
48 species in RENONES et al. (1997); 62 species in LETOURNEUR et al. (2003); and 47 species in PAIS et al. (2004)). However, those studies were conducted on a more variable range of habitats compared to this study which was limited to underwater cliffs. Interestingly, the most abundant fish species in all studies was C. chromis, becoming candidate for the most abundant fish species of the non-sandy infralittoral bottoms of the northern Mediterranean coasts. Furthermore, part of the C. chromis population is known to hide in cryptic bottom spaces even during daylight (KOVAČIĆ et al., 2012), so the total abundance of C. chromis is probably even larger than the abundance of the exposed visible individuals established by the present visual census. Unfortunately, in RENONES et al. (1997), LETOURNEUR et al. (2003) and PAIS et al. (2004) no data on average density of the whole sample was available for comparison.

In contrast to the other significant environmental variables that influence species composition, e.g. depth and inclination, bottom structure (bedrock with crevices and cavities or with more or less smooth surface) and biocover (zoocover, calcareous algae or long thallus algae), the high significance of eastern position for the fish assemblage structure is the only puzzling result among the explanatory variables. It is positively correlated with the second axis, and although the eastern position could be expected to have better sunlight conditions, its centroid position on the biplot (Fig. 3) is opposite to environmental variables that depend on sunlight e.g. long thallus algae. During the fieldwork, no prevailing influence of any particular depth, inclination, bottom structure or biocover was observed on the eastern transects, which is confirmed from the biplot where almost no other explanatory variables are directed near the eastern position centroid (Fig. 3 ). Another significant environmental variables in this study have clearly structured the fish assemblage and the results showed that the fish assemblages of deep, steep bedrock with crevices and cavities covered with sedentary animals and calcareous algae (P. phycis, L. mixtus, T. ephippiatus) or of the long thallus algae bottoms (Labridae, S. cantharus) are composed of species which presence there match our general knowledge of the species habitat preferences (JARDAS, 1996).

The abundance and species richness of the fish assemblages did not show significant variation with depths, inclinations, orientations and sites. However, in contrast to the results of previous studies (RENONES et al., 1997; LETOURNEUR et al., 2003; PAIS et al., 2004), we were able to find, by Permutational multivariate analysis of variance, the significant difference in fish assemblage among different depths, with the shallowest depth, 8-10 $\mathrm{m}$, having the most unique composition and with the gradient change of species composition with increasing depth down to the deepest transects at $45-50 \mathrm{~m}$ depth. This is consistent with the results of our Canonical correspondence analysis, which reveals depth as a highly significant environmental variable that influences species composition. LETOURNEUR et al. (2003), from the Canonical correspondence analysis, showed that depth in itself was not a significant factor explaining fish species patterns from 0 to $30 \mathrm{~m}$ depth and that the most significant factors were bottom substrate (sand) and biocover (macroalgae and Posidonica oceanica). The research carried out by PAIS et al. (2004) at 0 to $30 \mathrm{~m}$ depth was limited by the method to reveal significant differences in fish assemblage at different depths, as the depth as a factor was only tested by ANOVA for density of each fish species, with only two species, $C$. chromis and S. maena, showing significantly different density with depth. Finally, RENONES et al. (1997) showed by cluster analysis the greatest difference in similarity between their deeper stations at $41 \mathrm{~m}$ depth and all other stations and by correspondence analysis they found difference among block stations, vertical cliff stations and again for two deep stations at $41 \mathrm{~m}$ depth. The presently found depth importance for the fish assemblage structure was probably not established in previous three works probably for several reasons:

1) they did not focus any of their analyses primarily on depth as an environmental variable with appropriate hypothesis testing tool,

2) they mostly limited their analysis to the 
infralittoral zone while the present research was extended to the upper circalittoral,

3 ) in contrast to the more homogenous bottoms along the depth range in the present research, the variability of the involved bottom types in earlier researches could obscure the differences by depth in previous studies.

The present study did not compare the results of the video on underwater scooter method with the UVC and or with the DOV data. The simultaneous comparison, like in comparisons between UVC and DOV results (e.g. TESSIER et al., 2013), would be hard to achieve considering the speed of the underwater scooter against the diver swim. Slate recorded UVC requires a long underwater time to collect sufficient data and also requires divers who are experienced ichthyologists or others trained in identifying species and in some cases estimating individual fish sizes. However, it is well known that the slate recorded UVC gather better information as method since the video census is less accurate than standard UVC for determining species richness and video census also underestimates abundance, especially for low values (TESSIER et al., 2005). Anyway, the present video on underwater scooter method in combination with rebreather diving techniques could have two advantages, both over standard UVC and over DOV studies of fish assemblages, the decreased disturbance of fish assemblages and the greater depth that could be reached. Without pre-constructed transects, with the short time of smooth passage of the transect areas with the underwater scooter and with the noiseless breathing of the mixedgas closed-circuit rebreather the disturbance of fish assemblages should be greatly reduced compared to standard UVC and DOV methods. LINDFIELD et al. (2014) already showed that the use of the mixed-gas closed-circuit rebreather for fish surveys clearly minimizes behavioral biases associated with fish avoiding open-circuit SCUBA divers. The video on underwater scooter method in combination with the rebreather diving techniques also allows to reach greater depth, being faster with the underwater scooter and staying deeper and longer, thanks to the mixed gas closed circuit rebreather system, so the deeper underwater visual census could be the niche for the application of the new presented method.

Over the last thirty years, the faster alternative to the UVC, using underwater video techniques, has been introduced and used for assessing fish assemblages (GREENE \& ALEVISON, 1989, FRANCOUR et al., 1999; WILLIS \& BABCOCK, 2000; HARVEY et al., 2001). The ever increasing resolution and performance in low light conditions of each new generation of cameras and their sensors make underwater video census increasingly promising method. Over the last two decades, diving techniques with advanced dive equipment and different gas mixtures have been used to allow safe excursions to depths of 50-150 $\mathrm{m}$, which exceeds the depths that can be safely reached by conventional SCUBA (PARRISH \& PYLE, 2002). Despite these advances in SCUBA diving, few results have generally been published on the visual census of fish assemblages at depths of $50 \mathrm{~m}$ or deeper (BROKOVICH et al., 2008 to $65 \mathrm{~m}$ depth; BEJARANO et al., 2010; 2014 to 70 and $85 \mathrm{~m}$ depth; PINHEIRO et al., 2015 to 130 $\mathrm{m}$ depth), probably due to the increased logistical challenges associated with depth even today (ANDRADI-BROWN et al., 2016a; 2016b). Two diving techniques make it possible to approach to these depths. The first one is open-circuit trimix SCUBA equipment, which has rarely been used for studies of fishes, with the single example of collecting fishes in Mediterranean (GLAVIČIĆ \& KOVAČIĆ, 2016). However, gas spending of this open-circuit rig limited the effective bottom times at greater depths to no more than 12-15 minutes (PYLE, 1999) so its use is limited to short tasks. The second technique is mixed gas closed circuit rebreather (CCR) technology which is used even more rarely applied in studies of fishes than open-circuit trimix SCUBA technology (PARRISH \& PYLE, 2002; BEJARANO et al., 2014; PINHEIRO et al., 2015). Compared to open-circuit trimix SCUBA equipment, CCR has much higher autonomy underwater, decreases the risk of decompression sickness, reduces overall gas requirements, increases overall safety, and is bubble-free (PINHEIRO et al., 2015). These properties make it more promising for use in the visual 
census of deep bottom fish assemblages. However, CCR has serious limitations in terms of the price of equipment and the cost of fieldwork, as well as the need for highly skilled and trained CCR divers who must also be at the same time experts in fish species identification. The use of underwater video technique can overcome the later limitation by separating the CCR diving skills from the fish species identification knowledge. Rebreather diving techniques combined with the less time consuming visual census method thanks to the higher speed of the underwater scooter and the high quality video camera could make visual census studies below $40 \mathrm{~m}$, even down to $100 \mathrm{~m}$ depths, a standard method.

\section{ACKNOWLEDGMENTS}

This work is supported partially by the grant of the Croatian Science Foundation under the projects IP-2016-06-9884 and IP-2016-06-5251. We thank Ivana Štambuk for the English editing.

\section{REFERENCES}

ANDERSON, M.J. 2001. A new method for nonparametric multivariate analysis of variance. Austral. Ecology, 26(1): 32-46.

ANDRADI-BROWN D.A., C. MACAYA-SOLIS, D.A. EXTON, E. GRESS, G.WRIGHT \& A.D. ROGERS. 2016a. Assessing Caribbean Shallow and Mesophotic Reef Fish Communities Using Baited-Remote Underwater Video (BRUV) and Diver-Operated Video (DOV) Survey Techniques. PLoS ONE, 11 (12): e0168235. ANDRADI-BROWN, D.A., E. GRESS, G. WRIGHT, D.A. EXTON \& A.D. ROGERS. 2016b. Reef Fish Community Biomass and Trophic Structure Changes across Shallow to Upper-Mesophotic Reefs in the Mesoamerican Barrier Reef, Caribbean. PLoS ONE, 11(6): e0156641.

ARBIZU, P.M. 2019. PairwiseAdonis: Pairwise multilevel comparison using adonis. (https:// github.com/pmartinezarbizu/pairwiseAdonis). Accessed 15 September 2019.

ASSIS, J., B. CLARO, A. RAMOS, J. BOAVIDA \& E.A. SERRAO. 2013. Performing fish counts with a wide-angle camera, a promising approach reducing divers' limitations. Journal of Experimental Marine Biology and Ecology, 445: 93-98.

BEJARANO, I., M. NEMETH \& R.S. APPELDOORN. 2010. Use of mixed-gas rebreathers to access fish assemblages in mesophotic coral ecosystems (MCE) off La Parguera shelf-edge, Puerto Rico. In: Proceedings of the $63^{\text {rd }}$ Annual Gulf and Caribbean Fisheries Institute Meeting, 1-5 November 2010, San Juan, Puerto Rico: pp 130-133.
BEJARANO, I., R.S. APPELDOORN \& M. NEMETH. 2014. Fishes associated with mesophotic coral ecosystems in La Parguera, Puerto Rico. Coral Reefs 33: 313-328.

BORTONE, S. A., J. J. KIMMEL \& C.M. BUNDRICK. 1989. A Comparison of Three Methods for Visually Assessing Reef Fish Communities: Time and Area Compensated. Northeast Gulf Science, 10 (2): 85-96.

BROCK, V.E. 1954. A preliminary report on a method of estimating reef fish populations. The Journal of Wildlife Management, 18: 289-308.

BROKOVICH, E., S. EINBINDER, N. SHASHAR, M. KIFLAWI \& S. KARK. 2008. Descending to the twilight-zone: Changes in coral reef fish assemblages along a depth gradient down to 65 m. Marine Ecology Progress Series, 371: 253-262.

CALDWELL Z.R., B.J. ZGLICZYNSKI, G.J. WILLIAMS \& S.A. SANDIN. 2016. Reef Fish Survey Techniques: Assessing the Potential for Standardizing Methodologies. PLoS ONE 11(4): e0153066.

COLL, J., J. MORANTA, O. REÑONES, A. GARCIARUBIES \& I. MORENI. 1998. Influence of substrate and deployment time on fish assemblages on an artificial reef at Formentera Island (Balearic Islands, western Mediterranean). Hydrobiologia, 385: 139-182.

FASOLA, M., L. CANOVA, F. FOSCHI, O. NOVELLI \& M. BRESSAN. 1997. Resource use by a Mediterranean rocky slope fish assemblage. Marine Ecology, 18: 51-66. 
FIELD, J., K.R. CLARKE \& R.M. WARWICK.1982. A practical strategy for analyzing multispecies distribution patterns. Marine Ecology Progress Series, 8 (1): 37-52.

FRANCOUR, P., C. LIRET \& E. HARVEY. 1999. Comparison of fish abundance estimates made by remote underwater video and visual census. Naturalista siciliano, 23: 155-168.

GLAVIČIĆ, I. \& M. KOVAČIĆ. 2016. A quantitative sampling method for assessment of deep cryptobenthic ichthyofauna using trimix diving. Acta Ichthyologica et Piscatoria, 46 (1): 43-47.

GREENE, L.E. \& W.S. ALEVISON. 1989. Comparative accuracies of visual assessment methods for coral reef fishes. Bulletin of Marine Science, 44 (2): 899-912.

GUIDETTI, P., S. BUSSOTTI \& M. CONTI. 1998. Fish fauna of the Genoa-Quinto Posidonia oceanica bed (Ligurian Sea, North-Western Mediterranean). Rapp. Comm. int. Mer Medit., 35: 546-547.

GUIDETTI, P., A.TERLIZZI, S. FRASCHETTI \& F. BOERO. 2002. Spatio-temporal variability in fish assemblages associated with coralligenous formations in southeastern Apulia (SE Italy). Italian Journal of Zoology, 69: 325331.

HARMELIN-VIVIEN, M.L., J.G. HARMELIN, C. CHAUVET, C. DUVAL, R. GALZIN, P. LEJEUNE, G. BARNABE, F. BLANC, R. CHEVALIER, J. DUCLERC \& G. LASSERRE. 1985. Evaluation visuelle des peuplements et populations de poissons méthodes et problèmes. Rev Ecol (Terre Vie), 40: 467-539.

HARMELIN-VIVIEN, M.L. \& J.G. HARMELIN. 1975. Présentation d'une méthode d'évaluation in situ de la faune ichtyologique. Trav. sci. Parc nation. Port-Cros, 1: 47-52.

HARVEY, E.S. \& M. SHORTIS. 1996. A system for stereo-video measurement of subtidal organisms. Marine Technology Society Journal 29: $10-22$.

HARVEY, E.S., FLETCHER, D. \& M. SHORTIS. 2001. Improving the statistical power of visual length estimates of reef fish: A comparison of estimates determined visually by divers with estimates produced by a stereo-video system. Fishery Bulletin, 99(1): 72-80.
HOLMES, T.H., S.K. WILSON, M.J. TRAVERS, T.J. LANGLOIS, R.D. EVANS, G.I. MOORE, G. SHEDRAWI, E.S. HARVEY \& K. HICKLEY. 2013. A comparison of visual and stereo-video based fish community assessment methods in tropical and temperate marine waters of Western Australia. Limnology and Oceanography: Methods, 11: 337-350.

JARDAS, I. 1996. Jadranska ihtiofauna. Zagreb: Školska knjiga, pp. 533.

JIND, S. 2012. A comparison of two underwater visual sampling techniques used to estimate tropical reef fish communities. PhD Thesis, Dalhousie University, Halifax, Nova Scotia: p. 42.

KOVAČIĆ, M. 2002. A visual census of the coastal fish assemblage at Kostrena (the Kvarner area, Croatia). Annales Ser. hist. nat., 12(1): $1-8$.

KOVAČIĆ, M., R.A. PATZNER \& U.K. SCHLIEWEN. 2012. A first quantitative assessment of the ecology of cryptobenthic fishes in the Mediterranean Sea. Marine Biology, 159: 27312742.

LAM, K., P.K.S. SHIN, R. BRADBEER, D. RANDALL, K.K.K. KU, P. HODGSON \& S.G. CHEUNG. 2006. A comparison of video and point intercept transect methods for monitoring subtropical coral communities. Journal of Experimental Marine Biology and Ecology, 333: 115-128.

LETOURNEUR, Y., S. EUITTON \& S. SARTORETTO. 2003. Environmental and benthic habitat factors structuring the spatial distribution of a summer infralittoral fish assemblage in the north-western Mediterranean Sea. J. Mar. Biol. Ass. U.K., 83: 193-204.

LINDFIELD S.J, E.S. HARVEY, J.L. MCILWAIN \& A.R. HALFORD. 2014. Silent fish surveys: bubblefree diving highlights inaccuracies associated with SCUBA-based surveys in heavily fished areas. Methods in Ecology and Evolution 2014, 5: 1061-1069.

PAIS, A., E. AZZURRO \& L.A. CHESSA. 2004. Distribution patterns of coastal fish assemblages associated with different rocky substrates in Asinara island national park (Sardinia, Italy). Italian Journal of Zoology, 71: 309-316.

PARRISH, F.A. \& R.L. PYLE 2002. Field Comparison of Open-Circuit Scuba to Closed-Circuit 
Rebreathers for Deep Mixed-Gas Diving Operations. Marine Technology Society Journal, 36(2): 13-22.

PELLETIER, D., K. LELEU, G. MOU-THAM, N. GUILLEMOT \& P. CHABANET. 2011. Comparison of visual census and high definition video transects for monitoring coral reef fish assemblages. Fisheries Research, 107: 84-93.

PINHEIRO, H.T., G. GOODBODY-GRINGLEY, M.E. JESSUP, B. SHEPHERD, A.D. CHEQUER \& L.A. ROCHA. 2015. Upper and lower mesophotic coral reef fish communities evaluated by underwater visual censuses in two Caribbean locations. Coral Reefs, 35: 139-151. exploration. R.W. Hamilton, D. F. Pence, D. E. Kesling, Editors. Nahant, MA, USA: American Academy of Underwater Sciences, pp. 53-65.

PYLE, R.L. 1999. Mixed-gas, closed-circuit rebreather use for identification of new reef fish species from 200-500 fsw. In: Assessment and feasibility of technical diving operations for scientific exploration. R.W. Hamilton, D. F. Pence, D. E. Kesling, Editors. Nahant, MA, USA: American Academy of Underwater Sciences, pp. 53-65.

REÑONES, O., J. MORONTA, J. COLL, \& B. MORALESNIN. 1997. Rocky bottom fish communities of Cabrera Archipelago national Park (Mallorca, Western Mediterranean). Scientia Marina, 61 (4): 495-506.

SOLDO, A. \& I. GLAVIČIĆ. 2013. Fish communities and their depth distribution at vertical corraligen reefs in the Adriatic. Rapp. Commis. Inter. Mer Medit., 40: 776.

TER BRAAK, C.J.F. 1986. Canonical correspondence analysis: a new eigenvector method for multivariate direct gradient analysis. Ecology, 67: 1167-1179.

TER BRAAK, C.J.F. 1992. Permutation versus bootstrap significance tests in multiple regression and ANOVA. In: Jöckel KH, Rothe G, Sendler W, editors. Bootstrapping and Related Techniques. Lecture Notes in Economics and Mathematical Systems, vol. 376. Berlin, Heidelberg: Springer, pp. 79-85.

TER BRAAK, C.J.F. 1994. Canonical community ordination. Part I: Basic theory and linear methods. Ecoscience, 1(2): 127-140.

TESSIER, E., P. CHABANET, K. POTHIN, M. SORIA \& G. LASSERRE. 2005. Visual censuses of tropical fish aggregations on artificial reefs: slate versus video recording techniques. Journal of Experimental Marine Biology and Ecology, 3156: 17-30.

TESSIER, A., J. PASTOR, P. FRANCOUR, G. SARAGONI, R. CREC'HRIOU \& LENFANT. 2013. Video transects as a complement to underwater visual census to study reserve effect on fish assemblages. Aquatic Biology, 18: 229-241.

WARD-PAIGE, C., J. MILLS FLEMMING \& H.K. LOTZE. 2010. Overestimating Fish Counts by Non-Instantaneous Visual Censuses: Consequences for Population and Community Descriptions. PLoS ONE, 5(7): e11722.

WARTENBERG, R. \& A.J. BOOTH. 2015. Video transects are the most appropriate underwater visual census method for surveying highlatitude coral reef fishes in the southwestern Indian Ocean. Marine Biodiversity, 45: 633646.

WATSON, D.L., E.S. HARVEY, M.J. ANDERSON \& G.A. KENDRICK. 2005. A comparison of temperate reef fish assemblages recorded by three underwater stereo-video techniques. Marine Biology, 148: 415-425.

WILLIS, T.J. \& R.C. BABCOCK. 2000. A baited underwater video system for the determination of relative density of carnivorous reef fish. Marine and Freshwater Research, 51: 755-763.

Received: 17 June 2020

Accepted: 15 September 2020 


\title{
Utjecaj dubine na zajednicu riba stjenovitog dna u Mediteranu istraženu novom metodom videa sa podvodnog skutera
}

\author{
Igor GLAVIČIĆ, Marcelo KOVAČIĆ, Dejan PALISKA i Dani LASLO
}

Kontakt, e-pošta:marcelo@prirodoslovni.com

\begin{abstract}
SAŽETAK
Nova metoda videa sa podvodnog skutera uz rebreather ronilačku tehniku uvedena je i primjenjena za vizualni census zajednica riba. Ova metoda omogućuje istraživanja vizualnim cenzusom na dubinama većim od $40 \mathrm{~m}$, na kojima se, zbog teškoća u ronjenju na većim dubinama, vizualni cenzus rijetko izvodi. Metoda videa sa podvodnog skutera uz rebreather ronilačku tehniku također bi trebala biti manje uznemirujuća i brža u odnosu na plivajuće ronioce. Metoda je primjenjena u istraživanju vizualnim cenzusom na dubinama 8 do $50 \mathrm{~m}$ na dvije postaje na istočnom Jadranu sa 102 video transekta. Zabilježene su također varijable okoliša koje utječu na varijaciju u sastavu zajednice riba stjenovitog dna infralitorala i cirkalitorala.

Trideset i jedna vrsta riba je zabilježena, uz 10,3\% primjerka koji nisu određeni do razine vrste. Prosječna gustoća riba po transektu bila je 0,8 primjeraka $/ \mathrm{m}^{2}$, a najčešće i najbrojnije vrste bile su $C$. chromis, C. julis i G. auratus. Tri varijable okoliša: dubina, dno sa životinjskim obraštajem i istočna orjentacija dna, bile su izrazito značajne za prisutnost vrsta. Brojnost primjeraka i bogatstvo vrsta nisu pokazale značajnu promjenjivost sa promjenama dubine, nagiba, orjentacije i postaja. Utvrđena je značajna promjena u sastavu zajednice riba sa promjenom orjentacije obale, dubine i nagiba dna na transektima. Sastav vrsta postepeno se mijenjao sa porastom dubine dna i s povećanjem nagiba dna.
\end{abstract}

Ključne riječi: podvodni vizualni census, zajednica riba, video transekt, dubina, Jadransko more, rebreather zatvorenog kruga 